\title{
Targeting T cells in Chronic Inflammatory Bowel Diseases
}

\section{Flavio Caprioli ${ }^{1,2}$, Irene Marafini ${ }^{3}$, Federica Facciotti ${ }^{4}$, Francesco Pallone ${ }^{3}$, and Giovanni Monteleone ${ }^{3 *}$}

${ }^{1}$ Department of Pathophysiology and Transplantation, University of Milan, Milan, Italy

'Unit of Gastroenterology 2. Fondazione IRCCS Ca' Granda-Ospedale Maggiore Policlinico, Milan, Italy

${ }^{3}$ Department of Systems Medicine, University "Tor Vergata" of Rome, Rome, Italy

${ }^{4}$ Istituto Nazionale di Genetica Molecolare, Milan, Italy

\begin{abstract}
The pathological process that causes tissue damage in Crohn's disease (CD) and ulcerative colitis, the major inflammatory bowel diseases (IBD) in humans, is supposed to be mediated by distinct subsets of effector T cells, which accumulate in inflamed intestine of patients as a result of multiple mechanisms. These include enhanced recruitment of $T$ cells from the systemic circulation, increased cell cycling and resistance against apoptotic stimuli. Within the inflamed gut, effector T cells produce elevated levels of cytokines, which target multiple immune and nonimmune cell types thus contributing to amplify the detrimental inflammatory response. Strategies aimed at blocking T cell function in the gut have been employed with some success in patients with CD and patients with UC. This article summarizes the available data on T cell-directed therapies in IBD.
\end{abstract}

Keywords: IBD; Crohn's disease; Ulcerative colitis; Cytokines; AntiTNF; Anti-IL-12

\section{Introduction}

Crohn's disease (CD) and ulcerative colitis (UC), collectively known as inflammatory bowel diseases (IBD), represent a significant socioeconomic burden for western countries, due to their chronic and progressive disease course, which leads to frequent hospitalizations and surgical operations. The etiology of IBD remains unknown, but accumulating evidence suggests that environmental factors contribute to trigger in genetically predisposed individuals an exaggerated immune-inflammatory response against components of the luminal flora, which eventually leads to mucosal erosions, ulcers and fistulas [1]. Epidemiological and clinical observations in humans and studies in murine models of IBD suggest that $\mathrm{T}$ helper (Th) lymphocytes are master regulators of intestinal inflammation [2]. First, T cell accumulate heavily in inflamed gut of patients with CD and patients with UC. This phenomenon is the result of multiple mechanisms, including enhanced recruitment of cells from the systemic circulation due to high production of chemoattractants within the inflammatory microenvironment and regulated expression of adhesion molecules on vascular endothelium and integrins on T cells [3], increased cell cycling [4] and resistance of T cells against apoptotic stimuli [5]. Second, IBD ameliorates following the development of lymphopenia, such as that observed in patients with active HIV infection [6] or in patients undergoing bone-marrow transplantation [7]. Third, both CD and UC are frequently associated with other T-cell mediated diseases (i.e. psoriasis and multiple sclerosis) [8]. Fourth, colitis can be induced in immunodeficient mice by transfer of naïve T cells [9]. Fifth, strategies blocking T-cell function are useful for attenuating mucosal inflammation in mice with experimental colitis [10]. Altogether, these observations suggest that $\mathrm{T}$ cell blockers could be employed with success in IBD. In this context, it is however noteworthy that further cell types other than $\mathrm{T}$ cells contribute to sustain and amplify the tissue damaging-immune response in these disorders. Therefore, it is conceivable that other immunotherapeutic strategies, either alone or in combination with $\mathrm{T}$ cell-targeted therapy, could be used to dampen the IBD-associated pathogenic process in the next future [11-14]. In this article, we will summarize the available data on $\mathrm{T}$ cell-directed therapies in IBD.

\section{Induction of $\mathrm{T}$ cell apoptosis as a mechanism to control IBD- related mucosal inflammation}

$\mathrm{T}$ cell apoptosis is a critical mechanism aimed at preventing uncontrolled lymphocyte proliferation and preserving immune homeostasis. A specialized form of $\mathrm{T}$ cell apoptosis is represented by activation-induced cell death (AICD), which follows antigen-induced $\mathrm{T}$ cell stimulation and is mediated by the triggering of Fas (CD95) on T cell membrane by the cognate molecule Fas ligand (FasL) [15]. AICD apparatus is particularly relevant in the context of chronic antigenic stimulation, such as that occurring in the intestinal tract, where the mucosal immune system is constantly exposed to luminal antigens deriving from bacterial flora and diet. Indeed, apoptosis of intestinal T-lamina propria lymphocytes (T-LPL) is a physiological phenomenon in healthy individuals and normal intestinal T-LPL undergo apoptosis when stimulated in vitro with FasL [16]. In contrast, intestinal T-LPL of CD patients are resistant to Fas-mediated cell death and this defect has been associated with up-regulation of known inhibitors of Fas-driven apoptotic programs, such as Bcl-X(L) and Flip $[17,18]$. The functional relevance of resistance of $\mathrm{T}$ cells against apoptosis in the maintenance of $\mathrm{CD}$-associated tissue inflammation is supported by the demonstration that induction of intestinal T-LPL apoptosis is one of the main mechanisms of action of drugs already employed in the management of IBD patients, such as thiopurines and anti-TNF antibodies. The effectiveness of thiopurines (azathioprine/6-mercaptopurine) in CD has been recently confirmed by two meta-analyses reporting odds ratios of 2.43 and 2.32 for the induction and maintenance of clinical remission respectively as compared with placebo in active CD $[19,20]$. Tiede et al. demonstrated that azathioprine inhibits CD28-induced Racl activation, thereby reducing the activity of several anti-apoptotic

*Corresponding author: Giovanni Monteleone, Dipartimento di Medicina dei Sistemi, Università Tor Vergata, Via Montpellier, 1, 00133 Rome, Italy, Tel: +39.06.72596158; Fax: +39.06.72596391; E-mail: Gi.Monteleone@Med.uniroma2.it

Received June 18, 2013; Accepted July 26, 2013; Published July 31, 2013

Citation: Caprioli F, Marafini I, Facciotti F, Pallone F, Monteleone G (2013) Targeting T cells in Chronic Inflammatory Bowel Diseases. J Clin Cell Immunol 4: 155. doi:10.4172/2155-9899.1000155

Copyright: $\odot 2013$ Caprioli F, et al. This is an open-access article distributed under the terms of the Creative Commons Attribution License, which permits unrestricted use, distribution, and reproduction in any medium, provided the original author and source are credited. 
factors in $\mathrm{T}$ lymphocytes with the downstream effect of promoting apoptosis [21]. Enhanced rates of T cell death have been observed in CD tissue following administration of TNF- $a$ blockers, such as infliximab (a chimeric human/murine IgG1k antibody) [22] and adalimumab (a fully humanized IgG1k antibody) [23]. Overall, these drugs are able to induce and maintain one-year clinical remission in up to $70 \%$ and $45 \%$ patients with $\mathrm{CD}$ respectively, while the corresponding figures for UC are slightly lower [24-26]. In this context, infliximab is successfully employed as a rescue therapy in patients with acute severe colitis [27]. Interestingly, etanercept, a fusion protein that neutralizes both soluble and membrane-bound TNF with high affinity without inducing T-LPL apoptosis, is not beneficial in CD [28], supporting the hypothesis that the therapeutic efficacy of anti-TNF- $\alpha$ is strictly dependent on induction of T-LPL apoptosis. Various cytokines produced in inflamed tissue of IBD patients could contribute to make T-LPL resistant against apoptosis. For example, interleukin (IL)-6, IL-12, IL-15 and IL-21 can all activate signaling pathways that enhance anti-apoptotic molecules [2931]. Consistent with this is the demonstration that the beneficial effects of tocilizumab, an IgG1k monoclonal antibody directed against IL-6 receptor, and able to induce clinical response in up to $80 \%$ of patients with active $\mathrm{CD}$, are associated with induction of T-LPL apoptosis in $\mathrm{CD}[32]$.

\section{Inhibitors of $\mathrm{T}$ cell homing to gut tissue}

In the last two decades, work from several groups has greatly advanced our understanding of mechanisms regulating lymphocyte homing to the gut [3]. It is now evident that, in the gut, differentiation of naïve $\mathrm{T}$ cells into effector or regulatory subsets occurs mostly in 'inductive sites' (e.g. Peyer's patches and mesenteric lymph nodes) [33]. Differentiated $\mathrm{T}$ lymphocytes, which egress from these sites, enter the peripheral circulation and go back to the intestinal lamina propria. $\mathrm{T}$ cell trafficking in mucosal surfaces is mostly mediated by interactions between integrins (e.g. a4 $\beta 7$ ) expressed on leukocyte surface and cognate endothelial ligands (i.e. members of the immunoglobulin superfamily of adhesion molecules, intercellular adhesion molecule-1, mucosal addressin cell adhesion molecule- 1 and vascular cell adhesion molecule-1) [34]. To reduce recruitment of inflammatory cells to inflamed gut, several compounds have been developed and tested in IBD patients. One such a compounds is natalizumab, a monoclonal IgG4 antibody directed against the a4 subunit of integrins [35]. The levels of $\alpha 4 \beta 7$ integrin and its endothelial ligand, mucosal addressin cell adhesion molecule-1, are up-regulated in colons of IBD patients [36], while the numbers of $T$ lymphocytes expressing $\alpha 4 \beta 7$ are reduced in peripheral blood in patients with colonic inflammation [37], thus suggesting that the engagement of these molecules is associated with homing of gut-associated lymphocytes to inflamed colonic mucosa. Initial clinical trials showed that natalizumab was effective in inducing and maintaining remission in $\mathrm{CD}$ and $\mathrm{UC}$ patients [38,39], but unfortunately the use of natalizumab in IBD was halted when several cases of progressive multifocal encephalopathy (PML), a severe and potentially fatal neurologic disease, were documented in natalizumabtreated patients [40]. After a review of safety information, natalizumab was reintroduced in the USA with a surveillance program for the management of CD and finally approved by FDA in January 2008 for both induction and maintenance of remission in moderate to severe $\mathrm{CD}$. The drug has not been yet approved for CD in the European Union. More recently, vedolizumab (formerly MLN0002), an $\alpha 4 \beta 7$ integrin antagonist, and Etrolizumab (formerly rhuMAb Beta7), a humanized IgG1 monoclonal antibody targeting the $\beta 7$ integrin subunit, which specifically regulate migration of cells to the gut, have been used in IBD. Vedolizumab was beneficial in inducing and maintaining clinical response and remission in patients with $\mathrm{CD}$ [41] and patients with UC [42], with short-term response rates of $29 \%$ and $66 \%$ in CD and UC respectively. Vedolizumab administration was not associated with cases of PML or increased risk of severe side effects. A phase I clinical trial conducted in patients with moderate-to-severe UC showed that etrolizumab is well tolerated, even if a small proportion of patients experienced impaired wound healing following abdominal surgery. A clinical response was observed in 12/18 patients [43].

Homing of lymphocytes to the gut is also regulated by various chemokines produced by mucosal immune and non-immune cells. For example, interaction of CCL25, a chemokine expressed by small intestine epithelial cells, with CCR9 drives recruitment of T lymphocytes to the small intestine [44]. Thus, blockade of this pathway could be a promising therapeutic strategy in patients with ileal CD. CCX282-B (Traficet-EN), a small inhibitor of CCR9, showed clinical efficacy in up to $60 \%$ of patients with moderate-to-severe CD [45]. More recently, antagonists of CXCL10 (also known as IP10), a molecule implicated in chemoattraction of CXCR3expressing $\mathrm{T}$ cells have been tested in the treatment of patients with UC. BMS-936557, a fully human, monoclonal antibody to IP-10, induced clinical response has shown to induce clinical response in up to $53 \%$ of patients with moderate-to-severe UC, even though administration was associated with an enhanced rate of infections in comparison to placebo [46]. Another fully human monoclonal antibody against IP-10, named MDX-1100, is now under clinical evaluation in UC patients.

Alicaforsen (ISIS-2302) is an antisense oligonucleotide designed to inhibit the expression of ICAM-1, an endothelial molecule that selectively binds the integrin leukocyte function-associated antigen-1 expressed on leukocyte surface. Despite the initial and promising results, a randomized, placebo-controlled study documented no efficacy of alicaforsen in patients with active CD [47].

\section{Inhibitors of $\mathrm{T}$ cell proliferation and activation}

T-cell-receptor (TCR) engagement by antigen/MHC ligand initiates a complex signaling cascade culminating in the massive release of calcium in the cytoplasm and activation of calcineurin, a serine/ threonine phosphatase, which promotes nuclear factor of activated T-cells, cytoplasmic (NFATc)-dependent transcription of several genes involved in cell proliferation and cytokine production $[48,49]$. Consistently, pharmacological inhibition of calcineurin reduces TCRinduced $\mathrm{T}$ cell activation [50]. Cyclosporine and tacrolimus, two calcineurin inhibitors, are used for inducing and maintaining clinical response and remission in fistulizing $\mathrm{CD}[51,52]$ and in severe, steroidrefractory UC [53,54], even though both drugs can cause hypertension, paresthesiae and renal dysfunction especially in the long-term setting.

Engagement of TCR without simultaneous activation of costimulatory molecules on $\mathrm{T}$ cell surface (e.g. CD40L, CD28) by cognate antigen-presenting cell (APC) receptors (e.g. CD40, CD80, CD86) results in a state of $\mathrm{T}$ cell unresponsiveness, known as anergy [55]. For this reason, individual components of the immunological synapse', which sustains $\mathrm{T}$ cell activation, have been considered valid targets for designing novel anti-inflammatory compounds. Abatacept is a recombinant fusion protein composed of a fragment of IgG1 and the extracellular domain of cytotoxic T-lymphocyte antigen-4, a molecule which binds CD80 and CD86 with high affinity, thus preventing CD28mediated co-stimulation of T-cells [56]. Unfortunately, four placebocontrolled trials showed that abatacept was not effective in patients with CD and patients with UC [57]. 


\section{Inhibitors of $\mathrm{T}$ cell differentiation or $\mathrm{T}$ cell-derived cytokine function}

In response to activating stimuli, $\mathrm{T}$ cells can differentiate along specific pathways and become able to produce distinct subsets of cytokines. In this context, analysis of the cytokine milieu in inflamed gut of patients with CD and UC has led to the discovery that these two diseases are immunologically different. CD bears the stigmata of a $\mathrm{T}$ helper type 1 (Th1) disease characterized by excessive production of interferon (IFN)- $\gamma$, while the immune response in UC is mostly dominated by Th2-related cytokines, such as IL- 5 and IL-13, two Th2-related cytokines [58]. In this context, it is also noteworthy that active CD is associated with increased mucosal levels of IL-12, a Th1promoting cytokine [59], and T-bet and Stat4, two transcription factors that promote Th1 cell responses [60,61]. In both CD and UC there is also high production of cytokines (i.e. IL-17A, IL-17F and IL-26) made by another subset of polarized T cells, called Th17 cells [62], and elevated levels of IL-23, an APC-derived heterodimeric cytokine, which plays a major role in sustaining/stabilizing Th17 cell responses [63]. Since studies in experimental models of IBD have convincingly shown that $\mathrm{T}$ cell-derived cytokines are crucial in the initiation and progression of colitis, several pharmaceutical companies have developed drugs that interfere with $\mathrm{T}$ cell differentiation or $\mathrm{T}$ cell-derived cytokine function for the treatment of IBD. IL-12 and IL-23 are highly related heterodimeric cytokines, which share the common subunit, IL-12-p40 [64]. Therefore, neutralization of p40 subunit could offer the advantage to neutralize simultaneously two cytokines that govern Th1 and Th17 cell responses. Consistent with this, studies in mouse models of IBD confirmed that blockade of IL-12p40 is therapeutic [65]. However, clinical trials with various IL-12/IL-23 blockers in CD were quite disappointing. For example, apilimod mesylate, a small inhibitor of IL12 and IL-23 transcription, was not superior to placebo in controlling disease activity in patients with CD $[66,67]$. Similarly, ustekinumab, a monoclonal antibody targeting p40 subunit was only partially effective in patients with active $\mathrm{CD}$. After 6 week-treatment, clinical response was documented in $53 \%$ of patients given ustekinumab and $30 \%$ of those receiving placebo. However, at week 8, there was no significant difference in terms of clinical response between the two groups. A subgroup analysis demonstrated that $59 \%$ of patients who had previously been treated with infliximab responded to ustekinumab in comparison with $26 \%$ of patients treated with placebo $[68,69]$.

Additional results were generated with briakinumab, formerly known as ABT-874, another monoclonal antibody neutralizing p40 subunit. Despite the positive results obtained in an initial multicenter study [70], a larger phase IIb, randomized, controlled trial of 230 patients showed no benefit of briakinumab in the induction of remission at week six (primary endpoint), even though a modest benefit was seen in patients previously treated with anti-TNF agents [71]. Similarly, 3 different clinical trials showed no beneficial effect of fontolizumab, a monoclonal anti-IFN- $\gamma$ antibody, in patients with moderate to severe $\mathrm{CD}[72,73]$. Even more disappointing are the results obtained with Secukinumab, an anti-IL-17A monoclonal antibody, whose administration did not induce clinical response and remission in CD patients [74]. This later negative result could reflect the functional redundancy of Th17 effector cytokines. Indeed, in animal models of colitis, simultaneous blockade of IL-17A and IL-17F, and not neutralization of IL-17A, was necessary to dampen mucosal inflammation [75]. In humans, suppression of IL-17A and IL-17F production can be obtained with vidofludimus (formerly SC12267 or 4SC-101), a small molecule that inhibits the enzyme dihydroorotate dehydrogenase, involved in the de novo biosynthesis of pyrimidine by converting dihydroorotate to orotate [76]. There is preliminary evidence that vidofludimus attenuates chemical-induced colitis in mice [76] and can induce remission in both CD and UC patients when administered orally [77]. In a small open label uncontrolled study, 8 out of 14 (57.1\%) patients with CD and 6 out of $12(50.0 \%)$ patients with UC were in steroid-free remission after 12-week treatment [77].

IL-2 is the prototype member of the $\gamma$-chain family of cytokines, which also includes IL-4, IL-7, IL-9, IL-13, IL-15 and IL-21 [78]. Binding of IL-2 to its receptor activates several intracellular pathways, which promote proliferation and survival of $\mathrm{T}$ cells, thus amplifying $\mathrm{T}$ cell responses [79]. For this reason it was postulated that blockade of IL-2 function could be useful to control mucosal inflammation in IBD. Two monoclonal antibodies against the $\alpha$-chain of IL-2 receptor (CD25), named basiliximab and daclizumab, were tested in UC patients. Initial studies with basiliximab in steroid-resistant UC patients were very promising [80], but in 2012, a phase II randomized, placebo-controlled trial showed no clinical and endoscopic benefit [81]. Similarly, daclizumab had no therapeutic effect in patients with moderate-severe UC [82]. These negative results are not surprising, since there is no evidence that IL-2 is pathogenic in the gut. In contrast, it is well known that IL-2 can activate counter-regulatory pathways (e.g. development and maintenance of regulatory T cells) [83] and therefore blockade of IL-2 can make worse the pre-existing intestinal immune mediated pathology.

Janus Kinases (JAKs) are signaling molecules that act downstream a variety of cytokine receptors, hormone receptors and chemokines [84]. Tofacitinib (CP-690,550) is an oral inhibitor of JAK 1, 2 and 3, which interferes with Th2 and Th17 differentiation and blocks the secretion of IL-17 and IL-22 [85-87]. A multicenter, double blind, placebocontrolled, randomized trial has been recently carried out to text the efficacy of tofacitinib in patients with moderate-or-severe active UC [86]. Following 8 week-treatment clinical response was documented in $32 \%, 48 \%, 61 \%$, and $78 \%$ of patients receiving tofacitinib at a dose of $0.5 \mathrm{mg}(\mathrm{P}=0.39), 3 \mathrm{mg}(\mathrm{P}=0.55), 10 \mathrm{mg}(\mathrm{P}=0.10)$, and $15 \mathrm{mg}(\mathrm{P}<0.001)$, respectively, as compared with $42 \%$ of patients treated with placebo. Clinical remission occurred in $13 \%, 33 \%, 48 \%$, and $41 \%$ of patients treated with tofacitinib at a dose of $0.5 \mathrm{mg}(\mathrm{P}=0.76), 3 \mathrm{mg}(\mathrm{P}=0.01)$, $10 \mathrm{mg}(\mathrm{P}<0.001)$, and $15 \mathrm{mg}(\mathrm{P}<0.001)$, respectively, as compared with $10 \%$ of those treated with placebo. However, a dose-dependent increase in both low-density and high-density lipoprotein cholesterol was observed in tofacitinib-treated group [86].

\section{Conclusions}

In recent years, intensive basic and clinical research has enormously advanced our understanding of the mechanisms by which $\mathrm{T}$ cells amplify the mucosal inflammation that inexorably leads to tissue damage in IBD. Nonetheless, the vast majority of clinical trials with $\mathrm{T}$ cell blockers failed in IBD, raising important questions on which $\mathrm{T}$ cell pathways should be targeted in order to optimize therapeutic strategies. Altogether the accumulating data suggest that neutralization of single $\mathrm{T}$ cell-derived soluble cytokines is not effective and this could strictly rely on the fact that IBD-associated immune response is driven by multiple and disconnected cytokine networks. Indeed, it is now evident that tissue injury in IBD occurs in intestinal areas massively infiltrated with various subsets of cytokine-producing effector $\mathrm{T}$ cells. Therefore, targeting simultaneously two or more of effector cytokines could be more advantageous than inhibiting selectively a single cytokine. Since most cytokines over-produced in IBD tissue are redundant in their function, another therapeutic approach is to use compounds that act downstream cytokine receptors by inhibiting intracellular pathways. 
This hypothesis is supported by the clinical success seen in UC patients treated with tofacitinib. The lesson derived from the use of anti-TNF-a antibodies and immunosuppressors suggests that enhancing $\mathrm{T}$ cell apoptosis may be beneficial in IBD and this goal could be reached by antagonizing cytokines, which govern T cell survival and death (e.g. IL6, IL-15, IL-21). It should also be taken into consideration that not all the $\mathrm{T}$ cell-derived cytokines are produced during the different phases of IBD. Hence, administration of drugs blocking Th17 cytokines could be not useful in the early stages of CD that are marked by an IL-12associated Th1 cell response. In contrast, compounds inhibiting either Th1 or Th17 cytokines could be not sufficient to dampen the established phases of the disease, in which there is a predominant mixed Th1/Th17 cell response [88]. In conclusion, the data discussed in this article indicate that $\mathrm{T}$ cell-targeted therapy are useful in the management of IBD patients, even though further studies are needed to ascertain which patients could benefit from these treatments.

\section{Acknowledgments}

The authors received support for their work on T cells in IBD by "Fondazione Umberto Di Mario" (Rome, Italy) and Giuliani Spa (Milan, Italy).

\section{References}

1. Kaser A, Zeissig S, Blumberg RS (2010) Inflammatory bowel disease. Annu Rev Immunol 28: 573-621.

2. Maynard CL, Weaver CT (2009) Intestinal effector $T$ cells in health and disease. Immunity 31: 389-400.

3. Van Assche G, Rutgeerts P (2005) Physiological basis for novel drug therapies used to treat the inflammatory bowel diseases. I. Immunology and therapeutic potential of antiadhesion molecule therapy in inflammatory bowel disease. Am J Physiol Gastrointest Liver Physiol 288: G169-174.

4. Sturm A, Leite AZ, Danese S, Krivacic KA, West GA, et al. (2004) Divergent cell cycle kinetics underlie the distinct functional capacity of mucosal T cells in Crohn's disease and ulcerative colitis. Gut 53: 1624-1631.

5. Mudter J, Neurath MF (2007) Apoptosis of T cells and the control of inflammatory bowel disease: therapeutic implications. Gut 56: 293-303.

6. Pospai D, René E, Fiasse R, Farahat K, Beaugery L, et al. (1998) Crohn's disease stable remission after human immunodeficiency virus infection. Dig Dis Sci 43: 412-419

7. Oyama Y, Craig RM, Traynor AE, Quigley K, Statkute L, et al. (2005) Autologous hematopoietic stem cell transplantation in patients with refractory Crohn's disease. Gastroenterology 128: 552-563.

8. Delaporte $E$ (2008) [Immune-mediated inflammatory diseases and psoriasis]. Ann Dermatol Venereol 135 Suppl 4: S269-274.

9. Powrie F, Coffman RL, Correa-Oliveira R (1994) Transfer of CD4+ T cells to C.B-17 SCID mice: a model to study Th1 and Th2 cell differentiation and regulation in vivo. Res Immunol 145: 347-353

10. Monteleone G, Caprioli F (2010) T-cell-directed therapies in inflammatory bowel diseases. Clin Sci (Lond) 118: 707-715.

11. Musch E, Lutfi T, von Stein P, Zargari A, Admyre C, et al. (2013) Topical treatment with the Toll-like receptor agonist DIMS0150 has potential for lasting relief of symptoms in patients with chronic active ulcerative colitis by restoring glucocorticoid sensitivity. Inflamm Bowel Dis 19: 283-292.

12. http://clinicaltrials.gov/ct2/show/NCT01203631?term $=N$ N8555\&rank=2

13. Burt RK, Craig RM, Milanetti F, Quigley K, Gozdziak P, et al. (2010) Autologous nonmyeloablative hematopoietic stem cell transplantation in patients with severe anti-TNF refractory Crohn disease: long-term follow-up. Blood 116: 6123-6132.

14. Duijvestein M, Vos AC, Roelofs H, Wildenberg ME, Wendrich BB, et al. (2010) Autologous bone marrow-derived mesenchymal stromal cell treatment for refractory luminal Crohn's disease: results of a phase I study. Gut 59: 1662 1669 .

15. Alderson MR, Tough TW, Davis-Smith T, Braddy S, Falk B, et al. (1995) Fas ligand mediates activation-induced cell death in human $\mathrm{T}$ lymphocytes. J Exp Med 181: 71-77.
16. Boirivant M, Pica R, DeMaria R, Testi R, Pallone F, et al. (1996) Stimulated human lamina propria $T$ cells manifest enhanced Fas-mediated apoptosis. $J$ Clin Invest 98: 2616-2622.

17. Boirivant M, Marini M, Di Felice G, Pronio AM, Montesani C et al. (1999) Lamina propria T cells in Crohn's disease and other gastrointestinal inflammation show defective CD2 pathway-induced apoptosis. Gastroenterology 116: 557-565.

18. Monteleone I, Monteleone G, Fina D, Caruso R, Petruzziello C, et al. (2006) A functional role of flip in conferring resistance of Crohn's disease lamina propria lymphocytes to FAS-mediated apoptosis. Gastroenterology 130: 389-397.

19. Prefontaine E, Macdonald JK, Sutherland LR (2009) Azathioprine or 6-mercaptopurine for induction of remission in Crohn's disease. Cochrane Database Syst Rev: CD000545

20. Prefontaine E, Sutherland LR, Macdonald JK, Cepoiu M (2009) Azathioprine or 6-mercaptopurine for maintenance of remission in Crohn's disease. Cochrane Database Syst Rev: CD000067.

21. Tiede I, Fritz G, Strand S, Poppe D, Dvorsky R, et al. (2003) CD28-dependent Rac1 activation is the molecular target of azathioprine in primary human CD4+ T lymphocytes. J Clin Invest 111: 1133-1145.

22. ten Hove T, van Montfrans C, Peppelenbosch MP, van Deventer SJ (2002) Infliximab treatment induces apoptosis of lamina propria $T$ lymphocytes in Crohn's disease. Gut 50: 206-211.

23. Shen C, Assche GV, Colpaert S, Maerten P, Geboes K, et al. (2005) Adalimumab induces apoptosis of human monocytes: a comparative study with infliximab and etanercept. Aliment Pharmacol Ther 21: 251-258.

24. Targan SR, Hanauer SB, van Deventer SJ, Mayer L, Present DH, et al. (1997) A short-term study of chimeric monoclonal antibody CA2 to tumor necrosis factor alpha for Crohn's disease. Crohn's Disease cA2 Study Group. N Engl J Med 337: 1029-1035.

25. Hanauer SB, Feagan BG, Lichtenstein GR, Mayer LF, Schreiber S, et al (2002) Maintenance infliximab for Crohn's disease: the ACCENT I randomised trial. Lancet 359: 1541-1549.

26. Rutgeerts P, Sandborn WJ, Feagan BG, Reinisch W, Olson A, et al. (2005) Infliximab for induction and maintenance therapy for ulcerative colitis. N Engl J Med 353: 2462-2476.

27. Järnerot G, Hertervig E, Friis-Liby I, Blomquist L, Karlén P, et al. (2005) Infliximab as rescue therapy in severe to moderately severe ulcerative colitis: a randomized, placebo-controlled study. Gastroenterology 128: 1805-1811.

28. Sandborn WJ, Hanauer SB, Katz S, Safdi M, Wolf DG, et al. (2001) Etanercept for active Crohn's disease: a randomized, double-blind, placebo-controlled trial. Gastroenterology 121: 1088-1094.

29. Fukada T, Hibi M, Yamanaka Y, Takahashi-Tezuka M, Fujitani Y, et al. (1996) Two signals are necessary for cell proliferation induced by a cytokine recepto gp130: involvement of STAT3 in anti-apoptosis. Immunity 5: 449-460.

30. Estaquier J, Idziorek T, Zou W, Emilie D, Farber CM, et al. (1995) Thelper type $1 / T$ helper type 2 cytokines and T cell death: preventive effect of interleukin 12 on activation-induced and CD95 (FAS/APO-1)-mediated apoptosis of CD4+ cells from human immunodeficiency virus-infected persons. J Exp Med 182 1759-1767.

31. Masse GX, Corcuff E, Decaluwe H, Bommhardt U, Lantz O, et al. (2007) gamma(c) cytokines provide multiple homeostatic signals to naive CD4(+) $T$ cells. Eur J Immunol 37: 2606-2616.

32. Ito H, Takazoe M, Fukuda Y, Hibi T, Kusugami K, et al. (2004) A pilot randomized trial of a human anti-interleukin- 6 receptor monoclonal antibody in active Crohn's disease. Gastroenterology 126: 989-996.

33. Koboziev I, Karlsson F, Grisham MB (2010) Gut-associated lymphoid tissue T cell trafficking, and chronic intestinal inflammation. Ann N Y Acad Sci 1207 Suppl 1: E86-93.

34. Hart AL, Ng SC, Mann E, Al-Hassi HO, Bernardo D, et al. (2010) Homing of immune cells: role in homeostasis and intestinal inflammation. Inflamm Bowe Dis 16: 1969-1977.

35. Tubridy N, Behan PO, Capildeo R, Chaudhuri A, Forbes R, et al. (1999) The effect of anti-alpha4 integrin antibody on brain lesion activity in MS. The UK Antegren Study Group. Neurology 53: 466-472.

36. Souza HS, Elia CC, Spencer J, MacDonald TT (1999) Expression of lymphocyte-endothelial receptor-ligand pairs, alpha4beta7/MAdCAM-1 and 
OX40/OX40 ligand in the colon and jejunum of patients with inflammatory bowel disease. Gut 45: 856-863.

37. Meenan J, Spaans J, Grool TA, Pals ST, Tytgat GN, et al. (1997) Altered expression of alpha 4 beta 7, a gut homing integrin, by circulating and mucosal T cells in colonic mucosal inflammation. Gut 40: 241-246.

38. Sandborn WJ, Colombel JF, Enns R, Feagan BG, Hanauer SB, et al. (2005) Natalizumab induction and maintenance therapy for Crohn's disease. N Engl J Med 353: 1912-1925.

39. Gordon FH, Hamilton MI, Donoghue S, Greenlees C, Palmer T, et al. (2002) A pilot study of treatment of active ulcerative colitis with natalizumab, a humanized monoclonal antibody to alpha-4 integrin. Aliment Pharmacol Ther 16: 699-705.

40. Van Assche G, Van Ranst M, Sciot R, Dubois B, Vermeire S, et al. (2005) Progressive multifocal leukoencephalopathy after natalizumab therapy for Crohn's disease. N Engl J Med 353: 362-368.

41. Feagan BG, Greenberg G, Wild G, McDonald JW, Fedorak R, et al. (2003) Efficacy and safety of a humanized a4ß7 antibody in active Crohn's disease (CD). Gastroenterology 124: A25-26.

42. Feagan BG, Greenberg GR, Wild G, Fedorak RN, Paré P, et al. (2005) Treatment of ulcerative colitis with a humanized antibody to the alpha4beta7 integrin. N Engl J Med 352: 2499-2507.

43. Rutgeerts PJ, Fedorak RN, Hommes DW, Sturm A, Baumgart DC, et al. (2013) A randomised phase I study of etrolizumab (rhuMAb $\beta 7$ ) in moderate to severe ulcerative colitis. Gut 62: 1122-1130.

44. Zabel BA, Agace WW, Campbell JJ, Heath HM, Parent D, et al. (1999) Human G protein-coupled receptor GPR-9-6/CC chemokine receptor 9 is selectively expressed on intestinal homing $t$ lymphocytes, mucosal lymphocytes, and thymocytes and is required for thymus-expressed chemokine-mediated chemotaxis. J Exp Med 190: 1241-1256.

45. Walters MJ, Wang Y, Lai N, Baumgart T, Zhao BN, et al. (2010) Characterization of CCX282-B, an orally bioavailable antagonist of the CCR9 chemokine receptor, for treatment of inflammatory bowel disease. J Pharmacol Exp Ther 335: 61-69.

46. Mayer L, Sandborn WJ, Stepanov Y, Geboes K, Hardi R, et al. (2013) AntiIP-10 antibody (BMS-936557) for ulcerative colitis: a phase II randomised study. Gut

47. Yacyshyn B, Chey WY, Wedel MK, Yu RZ, Paul D, et al. (2007) A randomized, double-masked, placebo-controlled study of alicaforsen, an antisense inhibitor of intercellular adhesion molecule 1, for the treatment of subjects with active Crohn's disease. Clin Gastroenterol Hepatol 5: 215-220.

48. Liu JO (2009) Calmodulin-dependent phosphatase, kinases, and transcriptiona corepressors involved in T-cell activation. Immunol Rev 228: 184-198.

49. Okamura H, Aramburu J, García-Rodríguez C, Viola JP, Raghavan A, et al. (2000) Concerted dephosphorylation of the transcription factor NFAT1 induces a conformational switch that regulates transcriptional activity. Mol Cell 6: 539550 .

50. Shaw JP, Utz PJ, Durand DB, Toole JJ, Emmel EA, et al. (1988) Identification of a putative regulator of early t cell activation genes. Science 241: 202-205.

51. Present DH, Lichtiger S (1994) Efficacy of cyclosporine in treatment of fistula of Crohn's disease. Dig Dis Sci 39: 374-380.

52. Sandborn WJ, Present DH, Isaacs KL, Wolf DC, Greenberg E, et al. (2003) Tacrolimus for the treatment of fistulas in patients with Crohn's disease: a randomized, placebo-controlled trial. Gastroenterology 125: 380-388.

53. Campbell S, Travis S, Jewell D (2005) Ciclosporin use in acute ulcerative colitis: a long-term experience. Eur J Gastroenterol Hepatol 17: 79-84.

54. Ogata H, Matsui T, Nakamura M, lida M, Takazoe M, et al. (2006) A randomised dose finding study of oral tacrolimus (FK506) therapy in refractory ulcerative colitis. Gut 55: 1255-1262.

55. Tan P, Anasetti C, Hansen JA, Melrose J, Brunvand M, et al. (1993) Induction of alloantigen-specific hyporesponsiveness in human T lymphocytes by blocking interaction of CD28 with its natural ligand B7/BB1. J Exp Med 177: 165-173.

56. lannone F, Lapadula G (2012) The inhibitor of costimulation of $T$ cells: abatacept. J Rheumatol Suppl 89: 100-102.

57. Sandborn WJ, Colombel JF, Sands BE, Rutgeerts P, Targan SR, et al. (2012)
Abatacept for Crohn's disease and ulcerative colitis. Gastroenterology 143: 62-69.

58. Fuss IJ, Neurath M, Boirivant M, Klein JS, de la Motte C, et al. (1996) Disparate CD4+ lamina propria (LP) lymphokine secretion profiles in inflammatory bowel disease. Crohn's disease LP cells manifest increased secretion of IFNgamma, whereas ulcerative colitis LP cells manifest increased secretion of IL-5. J Immunol 157: 1261-1270.

59. Monteleone G, Biancone L, Marasco R, Morrone G, Marasco O, et al. (1997) Interleukin 12 is expressed and actively released by Crohn's disease intestinal lamina propria mononuclear cells. Gastroenterology 112: 1169-1178.

60. Mudter J, Weigmann B, Bartsch B, Kiesslich R, Strand D, et al. (2005) Activation pattern of signal transducers and activators of transcription (STAT) factors in inflammatory bowel diseases. Am J Gastroenterol 100: 64-72.

61. Neurath MF, Weigmann B, Finotto S, Glickman J, Nieuwenhuis E, et al (2002) The transcription factor T-bet regulates mucosal T cell activation in experimental colitis and Crohn's disease. J Exp Med 195: 1129-1143.

62. Caprioli F, Pallone F, Monteleone G (2008) Th17 immune response in IBD: A new pathogenic mechanism. J Crohns Colitis 2: 291-295.

63. Fuss IJ, Becker C, Yang Z, Groden C, Hornung RL, et al. (2006) Both IL12 p70 and IL-23 are synthesized during active Crohn's disease and are downregulated by treatment with anti-IL-12 p40 monoclonal antibody. Inflamm Bowel Dis 12: 9-15.

64. Trinchieri G, Pflanz S, Kastelein RA (2003) The IL-12 family of heterodimeric cytokines: new players in the regulation of T cell responses. Immunity 19: 641644.

65. Neurath MF, Fuss I, Kelsall BL, Stüber E, Strober W (1995) Antibodies to interleukin 12 abrogate established experimental colitis in mice. J Exp Med 182: $1281-1290$.

66. Burakoff R, Barish CF, Riff D, Pruitt R, Chey WY, et al. (2006) A phase 1/2A trial of STA 5326, an oral interleukin-12/23 inhibitor, in patients with active moderate to severe Crohn's disease. Inflamm Bowel Dis 12: 558-565.

67. Sands BE, Jacobson EW, Sylwestrowicz T, Younes Z, Dryden G, et al. (2010) Randomized, double-blind, placebo-controlled trial of the oral interleukin-12/23 inhibitor apilimod mesylate for treatment of active Crohn's disease. Inflamm Bowel Dis 16: 1209-1218.

68. Sandborn WJ, Feagan BG, Fedorak RN, Scherl E, Fleisher MR, et al (2008) A randomized trial of Ustekinumab, a human interleukin-12/23 monoclonal antibody, in patients with moderate-to-severe Crohn's disease. Gastroenterology 135: 1130-1141.

69. Sandborn WJ, Gasink C, Gao LL, Blank MA, Johanns J, et al. (2012) Ustekinumab induction and maintenance therapy in refractory Crohn's disease. N Engl J Med 367: 1519-1528.

70. Mannon PJ, Fuss IJ, Mayer L, Elson CO, Sandborn WJ, et al. (2004) Antiinterleukin-12 antibody for active Crohn's disease. N Engl J Med 351: 2069 2079 .

71. Panaccione R, Sandborn WJ, Gordon G (2010) Briakinumab (ABT874) for treatment of Crohn's disease. United European Gastroenterology Week 59: OP051D.

72. Reinisch W, Hommes DW, Van Assche G, Colombel JF, Gendre JP, et al (2006) A dose escalating, placebo controlled, double blind, single dose and multidose, safety and tolerability study of fontolizumab, a humanised antiinterferon gamma antibody, in patients with moderate to severe Crohn's disease. Gut 55: 1138-1144.

73. Reinisch W, de Villiers W, Bene L, Simon L, Rácz I, et al. (2010) Fontolizumab in moderate to severe Crohn's disease: a phase 2, randomized, double-blind, placebo-controlled, multiple-dose study. Inflamm Bowel Dis 16: 233-242.

74. Hueber W, Sands BE, Lewitzky S, Vandemeulebroecke M, Reinisch W, et al. (2012) Secukinumab, a human anti-IL-17A monoclonal antibody, for moderate to severe Crohn's disease: unexpected results of a randomised, double-blind placebo-controlled trial. Gut 61: 1693-1700.

75. Leppkes M, Becker C, Ivanov II, Hirth S, Wirtz S, et al. (2009) RORgammaexpressing Th17 cells induce murine chronic intestinal inflammation via redundant effects of IL-17A and IL-17F. Gastroenterology 136: 257-267.

76. Fitzpatrick LR, Small JS, Doblhofer R, Ammendola A (2012) Vidofludimus 
Citation: Caprioli F, Marafini I, Facciotti F, Pallone F, Monteleone G (2013) Targeting T cells in Chronic Inflammatory Bowel Diseases. J Clin Cell Immunol 4: 155. doi:10.4172/2155-9899.1000155

Page 6 of 6

inhibits colonic interleukin-17 and improves hapten-induced colitis in rats by a unique dual mode of action. J Pharmacol Exp Ther 342: 850-860

77. Herrlinger KR, Diculescu M, Fellermann K, Hartmann H, Howaldt S, et al. (2013) Efficacy, safety and tolerability of vidofludimus in patients with inflammatory bowel disease: The ENTRANCE study. J Crohns Colitis 7: 636643.

78. Rochman Y, Spolski R, Leonard WJ (2009) New insights into the regulation of T cells by gamma(c) family cytokines. Nat Rev Immunol 9: 480-490.

79. Liao W, Lin JX and Leonard WJ (2013) Interleukin-2 at the crossroads of effector responses, tolerance, and immunotherapy. Immunity 38: 13-25.

80. Creed TJ, Probert CS, Norman MN, Moorghen M, Shepherd NA, et al. (2006) Basiliximab for the treatment of steroid-resistant ulcerative colitis: further experience in moderate and severe disease. Aliment Pharmacol Ther 23: $1435-1442$.

81. Sands BE, Sandborn WJ, Creed TJ, Dayan CM, Dhanda AD, et al. (2012) Basiliximab does not increase efficacy of corticosteroids in patients with steroid-refractory ulcerative colitis. Gastroenterology 143: 356-364.

82. Van Assche G, Sandborn WJ, Feagan BG, Salzberg BA, Silvers D, et al (2006) Daclizumab, a humanised monoclonal antibody to the interleukin 2 receptor (CD25), for the treatment of moderately to severely active ulcerative colitis: a randomised, double blind, placebo controlled, dose ranging trial. Gut 55: 1568-1574

83. Setoguchi R, Hori S, Takahashi T, Sakaguchi S (2005) Homeostatic maintenance of natural Foxp3(+) CD25(+) CD4(+) regulatory T cells by interleukin (IL)-2 and induction of autoimmune disease by IL-2 neutralization. J Exp Med 201: 723-735.

84. O'Shea JJ, Plenge R (2012) JAK and STAT signaling molecules in immunoregulation and immune-mediated disease. Immunity 36: 542-550.

85. Changelian PS, Flanagan ME, Ball DJ, Kent CR, Magnuson KS, et al. (2003) Prevention of organ allograft rejection by a specific Janus kinase 3 inhibitor. Science 302: 875-878.

86. Sandborn WJ, Ghosh S, Panes J, Vranic I, Su C, et al. (2012) Tofacitinib, an oral Janus kinase inhibitor, in active ulcerative colitis. N Engl J Med 367 : 616-624.

87. Ghoreschi K, Jesson MI, Li X, Lee JL, Ghosh S, et al. (2011) Modulation of innate and adaptive immune responses by tofacitinib (CP-690,550). J Immunol 186: 4234-4243.

88. Zorzi F, Monteleone I, Sarra M, Calabrese E, Marafini I, et al. (2013) Distinct profiles of effector cytokines mark the different phases of Crohn's disease. PLoS One 8: e54562.
Citation: Caprioli F, Marafini I, Facciotti F, Pallone F, Monteleone G (2013) Targeting T cells in Chronic Inflammatory Bowel Diseases. J Clin Cell Immunol 4: 155. doi:10.4172/21559899.1000155

This article was originally published in a special issue, entitled: "Inflammatory Disorders", Edited by Dr. Kota V Ramana, University of Texas, USA
Submit your next manuscript and get advantages of OMICS Group submissions

\section{Unique features:}

User friendly/feasible website-translation of your paper to 50 world's leading languages

Audio Version of published paper

Digital articles to share and explore

Special features:

- 250 Open Access Journals

20,000 editorial team

- 21 days rapid review process

Quality and quick editorial, review and publication processing

- Indexing at PubMed (partial), Scopus, EBSCO, Index Copernicus and Google Scholar et

Sharing Option: Social Networking Enabled

- Authors, Reviewers and Editors rewarded with online Scientific Credits

- Better discount for your subsequent articles

Submit your manuscript at: www.editorialmanager.com/clinicalgroup 